\title{
Use of Online MOODLE to Create the Course to Improve Students' Fundamental Understanding
}

\author{
S. M. Dol ${ }^{1}$, S. A. Halkude ${ }^{2}$ \\ ${ }^{1}$ Computer Science and Engineering Department, Walchand Institute of Technology, Solapur, India \\ ${ }^{2}$ Computer Science and Engineering Department, Walchand Institute of Technology, Solapur, India \\ ${ }^{1}$ sunita_aher@yahoo.com \\ 2halkude60@gmail.com
}

\begin{abstract}
MOODLE (Modular Object-Oriented Dynamic Learning Environment) is free Learning Management System used for creating the courses in education sector. There are online MOODLE also available which can be used for this purpose. Online MOODLE like Gnomio or MoodleCloud are used to conduct small courses, Faculty Development Programme, etc. In the current study, the course on Database Engineering using online MOODLE and statistics of this course related to the usage is considered. This course was developed on online MOODLE Gnomio. This paper discusses the component of this course, statistics of usage of this course and feedback given by the students about this course.
\end{abstract}

Keywords: Database Engineering, MOODLE, Learning Dialogue(LeD), Learning by Doing (LbD), Learning Experience Interaction (LxI), Learning Experience Trajectories (LxT)

\section{Introduction}

Now days, online MOODLE platform is used for creating and conducting the courses. Moodle provides several opportunities for faculty members to transition from being 'the source of knowledge' to being a facilitator and role model in the process of knowledge and skills acquisition (Amandu, G. M. And et.al., 2013). As presented in (Blin F. and M. Munro, 2008), there are two different classes on the Moodle platform :resources and modules. The MOODLE platform provides several modules, such as Database, Lessons, Feedback, Labels, Assignments, Workshops, Chats, Forums, News, Glossary, Checklist, Wikis, Choice, Quiz, Survey, Feedback, Forum, Organizer, Book, File, Folder, SCORM (Sharable Content Object Reference Model) and External tools (http://moodle.org/).

\section{S. M. Dol}

${ }^{1}$ Computer Science and Engineering Department, Walchand Institute of Technology, Solapur, India sunita_aher@yahoo.com
Even it is possible to add block like Analytic Graphs, Completion Progress, Activity Result, Calendar, Comment, Blog Menu, Mentees, and Online Users etc.

In this current study, the course is created using online MOODLE https://www.gnomio.com/ and the course site is https://sunitamdoldbecourse1.gnomio.com/course/view.php ?id=2.

\section{Related Work}

In (S. Dol and et.al. , 2018), the MOODLE course on 'Active Learning: Think-Pair-Share and Peer Instruction Activity' was originally designed as part of FDP 301x "Mentoring Educators in Educational Technology" where the participation and effectiveness of the course was analyzed on three factors namely, engagement pattern of participants, learning in the course and perception of users towards the course.

In (Sunita M Dol and Trupti S Indi, 2017), Open Education Resource (OER): C-Programming Handout based Lab Session using MOODLE was developed which consists of C-Programming Lab handouts for First Year Engineering students. This OER contain the useful guidelines for implementing the program problem statement in the lab session. This OER was developed as a part of Four week Faculty Development Program sponsored by AICTE on "Use of ICT in Education for Online and Blended Learning" from 2nd May to 10th July 2016.

The article (Carolina Costa et.al., 2010) described a study carried out at the University of Aveiro (UA), Portugal that analyzed the functionalities and tools of the Moodle platform and their use by the students while a questionnaire-based study was conducted to evaluate the use of the Moodle-based e-learning platform of the German Jordanian University, Jordan (Rana El Bahsh and Mohammad I. Daoud, 2016).

The article (Andrea North-Samardzic and Monash University, 2015) suggested that theoretical models of technology acceptance and use needed to evolve to appropriately capture the environment of higher education in which learning management systems such as Moodle are used. In (Naifa E. Saleem et.al., 2016), the authors explored the acceptance of Moodle as a teaching and 
learning tool by the faculty of the Department of Information Studies (IS) at Sultan Qaboos University (SQU) in the Sultanate of Oman while the results of study (Lan Umek et.al, 2015) indicated that the implementation of an e-learning system (Moodle) at the Faculty of Administration, University of Ljubljana is related to a statistically significant increase in students' performance, measured as the average grade and the average number of admissions to the exams.

In the current article, I used various features along with peer assessment of assignment with the help of MOODLE activity Workshop.

\section{Online MOODLE for Course Creation}

MOODLE is an open-source learning management system to help educators create effective online learning communities. MOODLE is used for blended learning, distance education, flipped classroom and other elearning projects in schools, universities, workplaces and other sectors [https://en.wikipedia.org/wiki/Moodle]. This platform is used in education system where instructor adds material related to the specific course and activities for students to complete. MOODLE has various features like course creation, easy backup, assessment, collaborative tools and activities, convenient file management, analytics, embedding of external resources, content repository, managing user roles and permissions, multiple progress tracking options, notifications and automatic alerts, outcomes and rubrics, peer and self assessment, personalized dashboard etc. The benefits of MOODLE are user friendly interface, easy to customize, offline access, content management, security, assessment and testing, etc. [https://hurix.com/benefits-moodle-based-learning-

management-system/] I have used the online MOODLE https://www.gnomio.com/ for creating the course for the students. The URL for this course is https://sunitamdoldbecourse1.gnomio.com/course/view.php ?id=2 . The self enrolment feature is also added on the home page so that anyone can log into the course and go through it.

\section{Components of Course}

The components of course conducted for Database Engineering course of Third Year Computer Science and Engineering are given below in figure 1:

A. Welcome Note and Instructions

B. Course Entry Feedback

C. Introduction to DDL, DML, DCL and TCL

D. Learning Objectives

E. Learning Outcomes

F. Key Concepts

G. Topic-wise Contents

H. Discussion and Reflection Quiz

I. Advancing Your Learning

J. Database Application using DDL and DML

K. Evaluation and Feedback

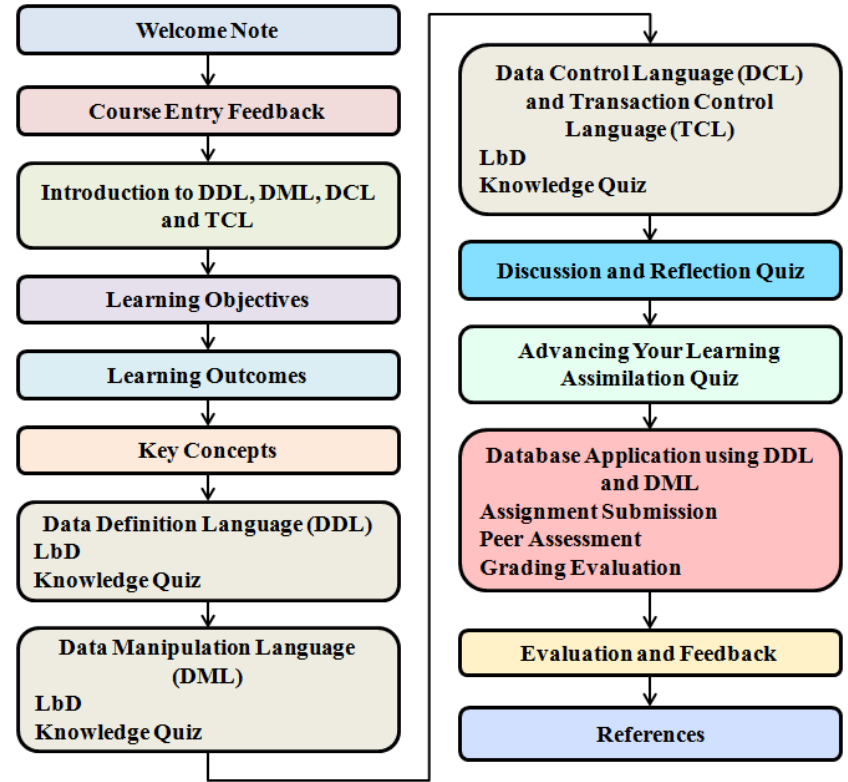

Fig. 1 Component of course

A. Welcome Note and Instructions:

This part contains the components of course and instructions about how to go through this course and attempt the same. This part also contains the important note.

\section{B. Course Entry Feedback}

Students entered course entry feedback which is used to know about the familiarity about the topics covered in the course. The question considered is - How much do you know about DDL, DML, DCL and TCL? The responses are given in the following table 1 .

Table 1: Course Entry Feedback of students

\begin{tabular}{|l|l|l|l|l|l|l|}
\hline $\begin{array}{l}\text { Choice } \\
\text { options } \rightarrow\end{array}$ & $\begin{array}{l}\text { Nothing } \\
\text { at all }\end{array}$ & Partially & $\begin{array}{l}\text { Know } \\
\text { about } \\
\text { DDL }\end{array}$ & $\begin{array}{l}\text { Know } \\
\text { about } \\
\text { DML }\end{array}$ & $\begin{array}{l}\text { Know } \\
\text { about } \\
\text { DCL }\end{array}$ & $\begin{array}{l}\text { Know } \\
\text { about } \\
\text { TCL }\end{array}$ \\
\hline $\begin{array}{l}\text { Number } \\
\text { of } \\
\text { responses }\end{array}$ & 22 & 30 & 21 & 16 & 1 & 1 \\
\hline
\end{tabular}

C. Introduction to DDL, DML, DCL and TCL

Here the introduction to the topics like DDL, DML, DCL and TCL are considered so that students will get some idea about this course as shown in figure 2 .

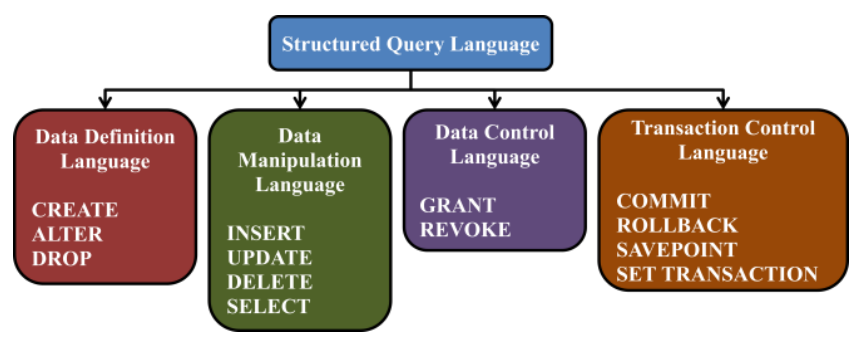

Fig. 2 Contents of course

D. Learning Objectives 
The Learning Objectives of this course are:

- $\quad$ To create, alter and drop the relation in database using Data Definition Language commands

- To insert, update and delete the relation in database using Data Manipulation Language commands

- To grant and revoke the privileges on the relation using Data Control Language commands

- To control the transaction using Transaction Control Language commands

E. Learning Outcome

At the end of this course, students will be able

- To create, alter and drop the tables in database for given application using Data Definition Language commands CREATE, ALTER and DROP command

- To insert, update and delete the data in database for given application using INSERT, UPDATE, and DELETE command.

- To use DCL commands GRANT and REVOKE to control the access of various database objects.

- To use TCL commands COMMIT, ROLLBACK, SAVEPOINT and SET TRANSACTION to control the transactions.

F. Key Concepts

Following are the key concepts of this course:

- $\quad$ Structured Query Language (SQL)

- Data Definition Language (DDL)

- Data Manipulation Language (DML)

- Data Control Language (DCL)

- Transaction Control Language (TCL)

G. Topic-wise Contents

This part contains three topics namely DDL, DML, and DCL \& TCL. Each topic contains Learning Dialogue (LeD), Learning by Doing (LbD) activities and one Knowledge Quiz.

Each LeD contains Learning Outcome, Reflection Spot, content following the Reflection Spot and References. Reflection spot is a point where the content is paused and the learner is required to answer a question asked based on the previously covered content. Reflection spot allows the learner to micro-practice or simply apply the concept that they have learnt immediately. Reflection spot may be a multiple-choice question, or fill in the blanks, or short answer question, etc. The goal of a learning dialog is to provide this conceptual knowledge along with explicit spots for learners to express their conceptions, do micro-practice and reflect on what they have learnt

Each LeD is followed by $\mathrm{LbD}$. $\mathrm{LbD}$ is a formative assessment activity for students to self-check their level of concept attainment, or for them to immediately apply the concepts that they have seen and learnt in the LeD, or for integration of various concepts and various parts of the module in the MOOC. This activity is designed by instructor.

Knowledge Quiz is a graded activity which was based on the topics covered in videos.
Topics considered are given below:

a) Data Definition Language (DDL)

i. LeD1: Data Definition Language (DDL) Video1

ii. LbD1: DDL Video1

iii. LeD2: Data Definition Language (DDL) Video2

iv. LbD2: DDL Video2

v. LeD3: Data Definition Language (DDL) Video3

vi. LbD3: DDL Video3

vii. Knowledge Quiz (KQ1) - DDL

b) Data Manipulation Language (DML)

i. LeD4: Data Manipulation Language (DML) Video1

ii. LbD4: DML Video1

iii. LeD5: Data Manipulation Language (DML) Video2

iv. LbD5: DML Video2

v. LeD6: Data Manipulation Language (DML) Video3

vi. LbD6: DML Video3

vii. Knowledge Quiz (KQ2) - DML

c) Data Control Language (DCL) and Transaction Control Language (TCL)

i. LeD7: Data Control Language (DCL)

ii. LbD7: DCL Video

iii. LeD8: Transaction Control Language (TCL)

iv. LbD8: TCL Video

v. Knowledge Quiz (KQ3) - DCL \& TCL

The videos created for above topics are also there in YouTube channel as:

- Video 1 - DDL CREATE Command https://www.youtube.com/watch?v=BGiIZgw9JHY

- Video 2 - DDL Constraints on CREATE Command https://www.youtube.com/watch?v=64XfUvdnoHc

- Video 3 - DDL ALTER and DROP Command https://www.youtube.com/watch?v=JjUOIURs3u4

- Video 4 - DML (Data Manipulation Language)INSERT Command

https://www.youtube.com/watch?v=p-C-kyUTXy0

- Video 5 - DML (Data Manipulation Language) UPDATE and DELETE Command https://www.youtube.com/watch? $\mathrm{v}=$ onpFu7eyqvg\&t= $\underline{23 \mathrm{~s}}$

- Video 6 - DML (Data Manipulation Language) SELECT Command https://www.youtube.com/watch?v=h-aNhOXDUTA

- $\quad$ Video 7 - DCL (Data Control Language) https://www.youtube.com/watch?v=vOooclQ5q_Y

- Video 8 - TCL (Transaction Control Language) https://www.youtube.com/watch?v=BttRblah-3s

H. Discussion and Reflection Quiz 
This part contains following two component

i. LxI - Learner Experience and Interaction (Discussion Forum) on DDL,DML,DCL and TCL

ii. RQ: Reflection Quiz

In LxI, focused question was given and following topics were assigned to the students for discussion.

Table 2: Topic assigned to students for discussion

\begin{tabular}{|l|l|l|}
\hline $\begin{array}{l}\text { Sr. } \\
\text { No. }\end{array}$ & Topic name & Roll No \\
\hline 1 & Retail Chain Management System & 1 to 10 \\
\hline 2 & Hospital Management System & 11 to 20 \\
\hline 3 & Library Management System & 21 to 30 \\
\hline 4 & Railway Reservation System & 31 to 40 \\
\hline 5 & Airline Reservation System & 41 to 50 \\
\hline 6 & Students Information System & 51 to 60 \\
\hline 7 & University & 61 to 70 \\
\hline 8 & Employee Information System & 71 onwards \\
\hline
\end{tabular}

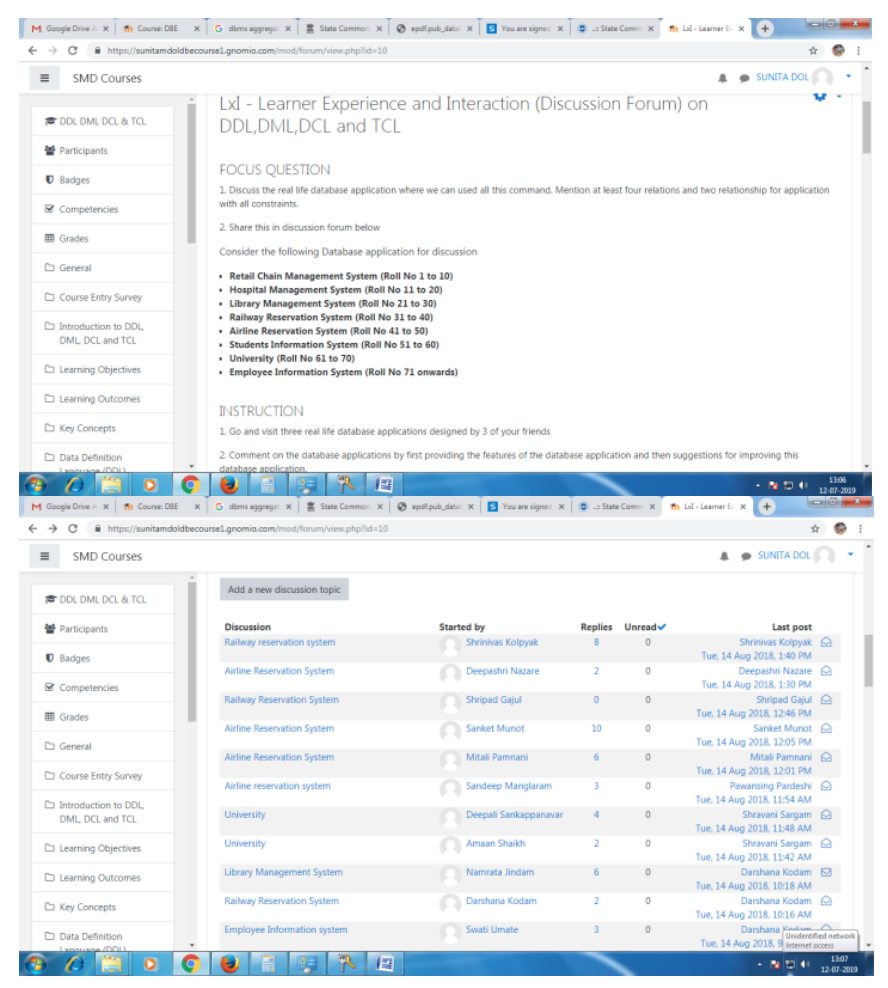

Fig. 3 Focus question and discussion by students in Learner Experience and Interaction (Discussion forum)

Reflection quiz helped the students to go back and review the discussions happened in order to answer the quiz questions. This quiz was based on discussion forum. The sample question is given here:

In the discussion thread started by Mahesh Jokare on Railway Reservation System, which ofthe following is the suggestion given by Pawansing Pardeshi

Select one:

a. You can add Aadhar number as an attribute to the passenger

b. You have provided good tuples...for better understanding describe primary key etc.

c. Mention Foreign Key also

d. There is no foreign key
I. Advancing Your Learning :

For Advancing your learning part of this FDP, two online sources were considered for advancing the students' knowledge about the Database Engineering course.

So this part of the FDP consist of:

i. Learning Extension Trajectories (LxT) 1: https://docs.oracle.com/cd/B14117_01/server.101/ b107

ii. Learning Extension Trajectories (LxT) 2: https://way2tutorial.com/sql/oracle_sql_introducti on $\mathrm{t}$

iii. Assimilation Quiz (AQ)

Assimilation Quiz ensure that student assimilate the key concept or knowledge intended from the resource

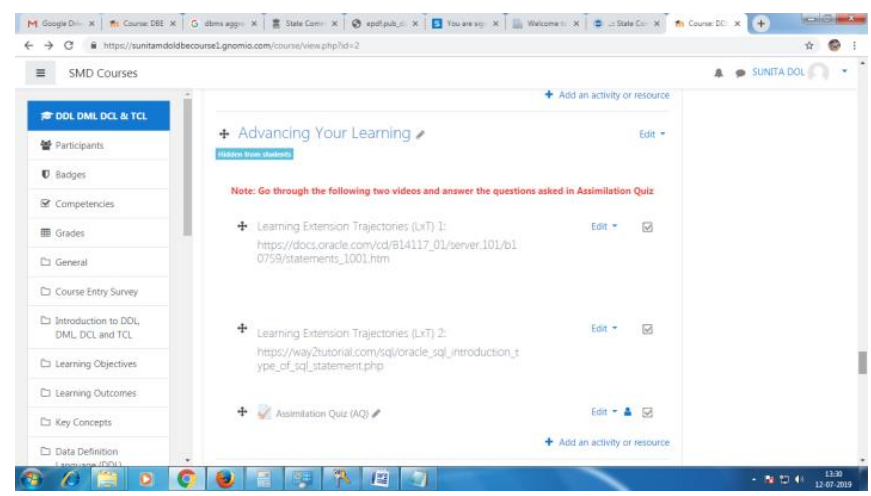

Fig. 4 Advancing Your Learning screenshot

J. Database Application using DDL and DML

This part contains:

1) Database Application using DDL and DML: Here the information about the database applications to be submitted by students and rubric to evaluate the assignment is given. Following table 3 represent the rubric to evaluate the assignment submitted by students.

Table 3: Rubric for Assignment evaluation

\begin{tabular}{|c|c|c|c|}
\hline & Present & $\begin{array}{l}\text { Partially } \\
\text { Present }\end{array}$ & Not \\
\hline $\begin{array}{l}\mathrm{CR} \\
\mathrm{Co}\end{array}$ & $\begin{array}{l}\text { CREATE } \\
\text { command is } \\
\text { present for all } \\
\text { mentioned relations } \\
\text { and relationships }\end{array}$ & $\begin{array}{l}\text { CREATE } \\
\text { command is } \\
\text { partially present } \\
\text { for mentioned } \\
\text { relations and } \\
\text { relationships }\end{array}$ & $\begin{array}{l}\text { CREATE } \\
\text { command is not } \\
\text { present for the } \\
\text { mentioned } \\
\text { relations and } \\
\text { relationships }\end{array}$ \\
\hline $\begin{array}{l}\text { Primary } \\
\text { Kay } \\
\text { Constraints }\end{array}$ & \begin{tabular}{|lr} 
Primary & Kay \\
Constraints & is \\
present for & all \\
\end{tabular} & \begin{tabular}{|lr} 
Primary & Kay \\
Constraints & is \\
partially & present \\
\end{tabular} & \begin{tabular}{|lr} 
Primary & Kay \\
Constraints & is \\
not present & for \\
\end{tabular} \\
\hline
\end{tabular}




\begin{tabular}{|c|c|c|c|}
\hline & $\begin{array}{l}\text { mentioned relations } \\
\text { and relationships }\end{array}$ & \begin{tabular}{|l} 
for mentioned \\
relations and \\
relationships
\end{tabular} & $\begin{array}{l}\text { the mentioned } \\
\text { relations and } \\
\text { relationships }\end{array}$ \\
\hline $\begin{array}{l}\text { Foreign } \\
\text { key } \\
\text { constraints }\end{array}$ & $\begin{array}{l}\text { Foreign key } \\
\text { constraints is } \\
\text { present for all } \\
\text { mentioned relations } \\
\text { and relationships }\end{array}$ & $\begin{array}{l}\text { Foreign } r \text { key } \\
\text { constraints is } \\
\text { partially present } \\
\text { for mentioned } \\
\text { relations and } \\
\text { relationships }\end{array}$ & $\begin{array}{l}\text { Foreign key } \\
\text { constraints is } \\
\text { not present for } \\
\text { the mentioned } \\
\text { relations and } \\
\text { relationships }\end{array}$ \\
\hline $\begin{array}{l}\text { ALTER } \\
\text { command }\end{array}$ & $\begin{array}{l}\text { More than one } \\
\text { ALTER commands } \\
\text { are present. }\end{array}$ & \begin{tabular}{|lr} 
Only & one \\
ALTER & \\
command & is \\
present & \\
\end{tabular} & $\begin{array}{l}\text { ALTER } \\
\text { command is not } \\
\text { present }\end{array}$ \\
\hline $\begin{array}{l}\text { DROP } \\
\text { command }\end{array}$ & $\begin{array}{l}\text { DROP command is } \\
\text { present. }\end{array}$ & & $\begin{array}{l}\text { DROP } \\
\text { command is not } \\
\text { present }\end{array}$ \\
\hline $\begin{array}{l}\text { INSERT } \\
\text { command }\end{array}$ & $\begin{array}{l}\text { INSERT command } \\
\text { is present for all } \\
\text { mentioned relations } \\
\text { and relationships }\end{array}$ & $\begin{array}{l}\text { INSERT } \\
\text { command is } \\
\text { partially present } \\
\text { for mentioned } \\
\text { relations and } \\
\text { relationships }\end{array}$ & $\begin{array}{l}\text { INSERT } \\
\text { command is not } \\
\text { present for the } \\
\text { mentioned } \\
\text { relations and } \\
\text { relationships }\end{array}$ \\
\hline $\begin{array}{l}\text { UPDATE } \\
\text { command }\end{array}$ & $\begin{array}{l}\text { More than one } \\
\text { ALTER commands } \\
\text { are present. }\end{array}$ & \begin{tabular}{|lr} 
Only & one \\
ALTER & \\
command & is \\
present & \\
\end{tabular} & $\begin{array}{l}\text { ALTER } \\
\text { command is not } \\
\text { present }\end{array}$ \\
\hline $\begin{array}{l}\text { DELETE } \\
\text { command }\end{array}$ & $\begin{array}{l}\text { DELETE } \\
\text { command }\end{array}$ & & $\begin{array}{l}\text { DELETE } \\
\text { command is not }\end{array}$ \\
\hline
\end{tabular}

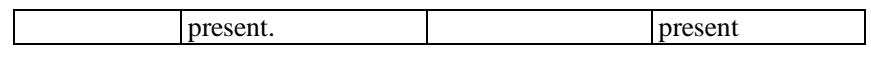

2) Database Application using DDL and DML Example Sample: Here the sample example of assignment was given so that students can understand what is to submitted in the assignments.

3) Database Application using DDL and DML Assignment Submission: Workshop activity was used for assignment submission and evaluation. After submission of the assignment, peer evaluation was done. Here each student was assigned three peers to evaluate the assignment. Peer Assessment using MOODLE activity- workshop is shown in figure 5.

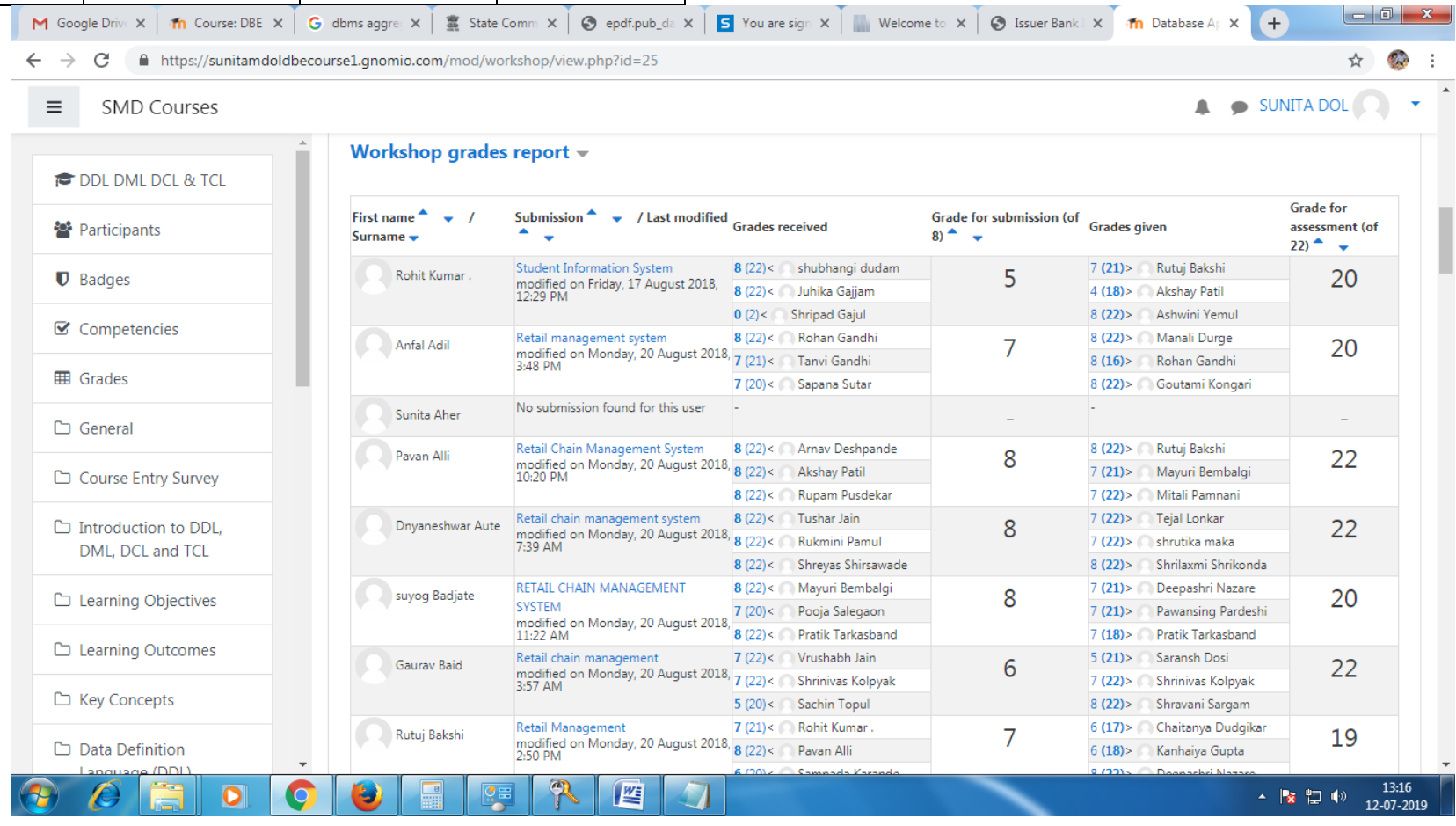

Fig. 5 Peer Assessment using MOODLE activity- workshop

K. Evaluation and Feedback

Here three types of feedback were considered for analyzing the overall perception of students:

i. Perception of Learning:

https://docs.google.com/forms/d/e/1FAIpQLSefd

VgyXp7kBdBZBusXrZirL

ii. Perception of Engagement:

https://docs.google.com/forms/d/e/1FAIpQLSeZ1 Uqom0sfF5L17kHjmGxmR iii. Perception of Usability: https://docs.google.com/forms/d/e/1FAIpQLSd3R dOOlvCIDgHQo6i2pMRD-

\section{References}

References used while designing this course are considered in this part of course. 
This small course was conducted was conducted from $7^{\text {th }}$ August to $27^{\text {th }}$ August 2018. The details about the course content and count is given in table 4 while course content and deadline for each activity are given in the Table 5 .

Table 4: Course contents and count

\begin{tabular}{|l|l|l|}
\hline Sr. No. & Content & Number \\
\hline 1 & LeD & 8 \\
\hline 2 & LbD & 8 \\
\hline 3 & KQ & 3 \\
\hline 4 & LxI & 1 \\
\hline 5 & RQ & 1 \\
\hline 6 & LxT & 2 \\
\hline 7 & AQ & 1 \\
\hline 8 & Assignment using Workshop & 1 \\
\hline 9 & Feedback & 3 \\
\hline
\end{tabular}

Table 5: Course Content and Deadline

\begin{tabular}{|c|c|c|c|}
\hline Sr. & \multicolumn{2}{|l|}{ Content } & Deadline \\
\hline \multirow[b]{2}{*}{1} & \multirow{2}{*}{$\begin{array}{l}\text { Data Definition } \\
\text { Language (DDL) }\end{array}$} & LbD & \multirow{2}{*}{$\begin{array}{c}7^{\text {th }} \text { August to } 8^{\text {th }} \text { August } \\
2018\end{array}$} \\
\hline & & $\begin{array}{l}\text { Knowledge } \\
\text { Quiz }\end{array}$ & \\
\hline \multicolumn{4}{|c|}{ Discussion and doubt solving session in the classroom $-9^{\text {th }}$ August 2018} \\
\hline \multirow[b]{2}{*}{2} & \multirow{2}{*}{$\begin{array}{l}\text { Data } \\
\text { Manipulation } \\
\text { Language } \\
\text { (DML) }\end{array}$} & $\mathrm{LbD}$ & \multirow[b]{2}{*}{$9^{\text {th }}$ August 2018} \\
\hline & & $\begin{array}{l}\text { Knowledge } \\
\text { Quiz }\end{array}$ & \\
\hline \multicolumn{4}{|c|}{ Discussion and doubt solving session in the classroom $-10^{\text {th }}$ August 2018} \\
\hline \multirow[b]{2}{*}{3} & \multirow{2}{*}{$\begin{array}{l}\text { Data Control } \\
\text { Language } \\
\text { (DCL) and } \\
\text { Transaction } \\
\text { Control } \\
\text { Language } \\
\text { (TCL) }\end{array}$} & $\mathrm{LbD}$ & \multirow[b]{2}{*}{$10^{\text {th }}$ August 2018} \\
\hline & & $\begin{array}{l}\text { Knowledge } \\
\text { Quiz }\end{array}$ & \\
\hline \multicolumn{4}{|c|}{ Discussion and doubt solving session in the classroom - $11^{\text {th }}$ August 2018} \\
\hline 4 & $\begin{array}{l}\text { Discussion and } \\
\text { Reflection Quiz }\end{array}$ & Reflection Quiz & $\begin{array}{c}11^{\text {th }} \text { August to } 14^{\text {th }} \\
\text { August } 2018 \\
\end{array}$ \\
\hline \multicolumn{4}{|c|}{ Discussion and doubt solving session in the classroom $-13^{\text {th }}$ August 2018} \\
\hline 5 & $\begin{array}{l}\text { Advancing Your } \\
\text { Learning }\end{array}$ & $\begin{array}{l}\text { Assimilation } \\
\text { Quiz }\end{array}$ & $\begin{array}{c}14^{\text {th }} \text { August and } 15^{\text {th }} \\
\text { August } 2018\end{array}$ \\
\hline \multicolumn{4}{|c|}{ Discussion and doubt solving session in the classroom $-16^{\text {th }}$ August 2018} \\
\hline \multirow{3}{*}{6} & \multirow{3}{*}{$\begin{array}{l}\text { Database } \\
\text { Application } \\
\text { using DDL and } \\
\text { DML }\end{array}$} & $\begin{array}{l}\text { Assignment } \\
\text { Submission }\end{array}$ & $\begin{array}{c}16^{\text {th }} \text { August to } 20^{\text {th }} \\
\text { August } 2018\end{array}$ \\
\hline & & $\begin{array}{l}\text { Peer } \\
\text { Assessment }\end{array}$ & $\begin{array}{c}21^{\text {st }} \text { August to } 23^{\text {rd }} \\
\text { August } 2018\end{array}$ \\
\hline & & $\begin{array}{l}\text { Grading } \\
\text { Evaluation }\end{array}$ & $\begin{array}{c}24^{\text {th }} \text { August and } 25^{\text {th }} \\
\text { August } 2018\end{array}$ \\
\hline \multicolumn{4}{|c|}{ Discussion and doubt solving session in the classroom $-18^{\text {th }}$ August } \\
\hline \multicolumn{4}{|c|}{$2018,22^{\text {nd }}$ August 2018} \\
\hline 7 & $\begin{array}{l}\text { Evaluation and } \\
\text { Feedback }\end{array}$ & Feedback & $\begin{array}{c}24^{\text {th }} \text { August to } 27^{\text {th }} \\
\text { August } 2018\end{array}$ \\
\hline
\end{tabular}

\section{Evaluation Report}

Research Question: Is this course created using online MOODLE useful?

A. Analysis of Engagement

The activity completion report generated from the course Reports section shows the engagement of participants in the activities as shown in Table 6 while the graph is shown in figure 6.

Table 6: Activity Completion Summary

\begin{tabular}{|c|c|c|}
\hline \multicolumn{2}{|l|}{ Activity } & $\begin{array}{l}\text { Completion } \\
\text { Status }\end{array}$ \\
\hline \multicolumn{2}{|l|}{ Course Entry Survey } & 69 \\
\hline \multirow{8}{*}{$\begin{array}{l}\text { LeDs } \\
\text { (Learning Dialogue) }\end{array}$} & 1 & 71 \\
\hline & 2 & 71 \\
\hline & 3 & 71 \\
\hline & 4 & 70 \\
\hline & 5 & 69 \\
\hline & 6 & 67 \\
\hline & 7 & 71 \\
\hline & 8 & 70 \\
\hline \multirow{8}{*}{$\begin{array}{l}\text { LbDs } \\
\text { (Learning by Doing) }\end{array}$} & 1 & 71 \\
\hline & 2 & 71 \\
\hline & 3 & 71 \\
\hline & 4 & 66 \\
\hline & 5 & 66 \\
\hline & 6 & 66 \\
\hline & 7 & 70 \\
\hline & 8 & 70 \\
\hline \multirow{3}{*}{$\begin{array}{l}\text { KQ } \\
\text { (Knowledge Quiz) }\end{array}$} & 1 & 69 \\
\hline & 2 & 66 \\
\hline & 3 & 69 \\
\hline \multicolumn{2}{|c|}{$\begin{array}{l}\text { Learner Experience and Interaction } \\
\text { (Discussion Forum) on DDL,DML,DCL and } \\
\text { TCL }\end{array}$} & 69 \\
\hline \multicolumn{2}{|l|}{ RQ (Relection Quiz) } & 67 \\
\hline \multicolumn{2}{|c|}{ LxT1 (Learning Extension Trajectories) } & 69 \\
\hline \multicolumn{2}{|c|}{ LxT2 (Learning Extension Trajectories) } & 69 \\
\hline \multicolumn{2}{|l|}{ AQ (Assimilation Quiz) } & 59 \\
\hline \multicolumn{2}{|c|}{$\begin{array}{l}\text { Design Database Application using DDL and } \\
\text { DML }\end{array}$} & 70 \\
\hline \multicolumn{2}{|c|}{$\begin{array}{l}\text { Peer Database Application using DDL and } \\
\text { DML }\end{array}$} & 70 \\
\hline
\end{tabular}

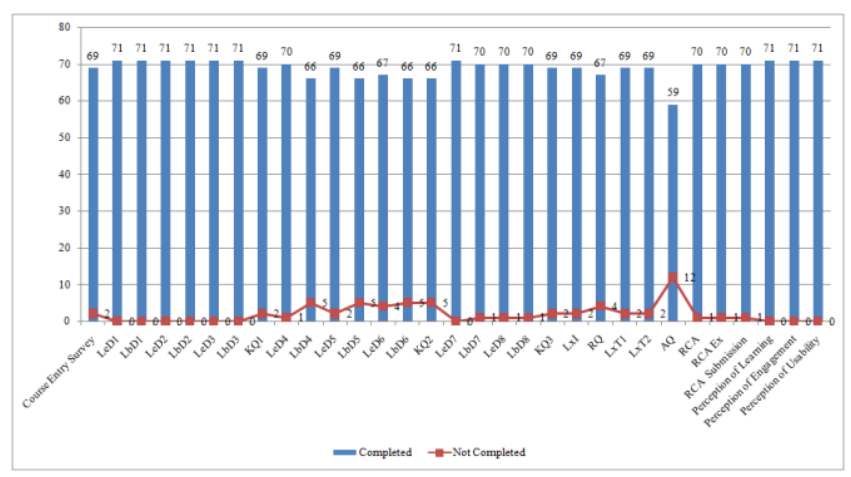

Fig. 6 Activity Completion Graph

B. Analysis of Learning

Analysis of the learning of the students is done by analyzing the marks obtained by the participants in attempting various quizzes and activities. There were five types of quizzes and activities for the participants.

The average mark for each of them is given below:

Learning by Doing (LbD) Activities- 8 Nos [32 marks] 
Reflection Quiz- 1 Nos [08 marks]

Assimilation Quiz- 1 Nos [08 marks]

Knowledge Quiz - 3 Nos [22 marks]

Design and Peer Review of Database Application using DDL and DML [30 marks]

Total 100 marks

Number of participants who attempted each activity, the average marks and percentage they scored are given in the Table 7.

Table 7: Number of participants who attempted each activity, the average marks and percentage they scored

\begin{tabular}{|l|l|l|l|l|l|l|l|l|l|}
\hline & LbDs & $\begin{array}{l}\text { K } \\
\text { Q1 }\end{array}$ & $\begin{array}{l}\text { K } \\
\mathbf{Q} \\
\mathbf{2}\end{array}$ & $\begin{array}{l}\text { K } \\
\mathbf{Q 3}\end{array}$ & $\mathbf{R Q}$ & $\begin{array}{l}\mathbf{A} \\
\mathbf{Q}\end{array}$ & $\begin{array}{l}\text { RC } \\
\mathbf{A}\end{array}$ & Any & All \\
\hline $\begin{array}{l}\text { No of } \\
\text { students } \\
\text { attempted }\end{array}$ & 71 & 69 & 66 & 69 & 67 & $\begin{array}{l}5 \\
9\end{array}$ & 70 & 71 & 53 \\
\hline $\begin{array}{l}\text { Average } \\
\text { marks }\end{array}$ & 29 & 5 & 6 & 5 & 7 & 7 & 27 & 84 & 89 \\
\hline $\begin{array}{l}\text { Maximum } \\
\text { marks }\end{array}$ & 32 & 8 & 8 & 6 & 8 & 8 & 30 & 100 & 100 \\
\hline $\begin{array}{l}\text { Average } \\
\text { percentage }\end{array}$ & $90 \%$ & 83 & $\begin{array}{l}10 \\
\%\end{array}$ & $\begin{array}{l}83 \\
\%\end{array}$ & $\begin{array}{l}88 \\
\%\end{array}$ & $\begin{array}{l}8 \\
8\end{array}$ & $\begin{array}{l}9 \\
\%\end{array}$ & $84 \%$ & $89 \%$ \\
\hline
\end{tabular}

Table 8: Number of participants who attempted each LbDs

\begin{tabular}{|l|l|l|l|l|l|l|l|l|l|l|}
\hline LbDs & $\begin{array}{l}\text { Lb } \\
\text { D1 }\end{array}$ & $\begin{array}{l}\text { Lb } \\
\text { D2 }\end{array}$ & $\begin{array}{l}\text { Lb } \\
\text { D3 }\end{array}$ & $\begin{array}{l}\text { Lb } \\
\text { D4 }\end{array}$ & $\begin{array}{l}\text { Lb } \\
\text { D5 }\end{array}$ & $\begin{array}{l}\text { Lb } \\
\text { D6 }\end{array}$ & $\begin{array}{l}\text { Lb } \\
\text { D7 }\end{array}$ & $\begin{array}{l}\text { Lb } \\
\text { D8 }\end{array}$ & $\begin{array}{l}\text { Any } \\
\text { of the } \\
\text { LbDs }\end{array}$ & $\begin{array}{l}\text { All of } \\
\text { the } \\
\text { LbDs }\end{array}$ \\
\hline $\begin{array}{l}\text { No of } \\
\text { Perso } \\
\text { ns } \\
\text { attem } \\
\text { pted }\end{array}$ & 71 & 71 & 71 & 66 & 66 & 66 & 70 & 70 & 71 & 65 \\
\hline $\begin{array}{l}\text { Avera } \\
\text { ge } \\
\text { marks }\end{array}$ & 4 & 3 & 4 & 4 & 4 & 2 & 4 & 4 & 3.6 & 3.5 \\
\hline $\begin{array}{l}\text { Maxi } \\
\text { mum } \\
\text { marks }\end{array}$ & 4 & 4 & 4 & 4 & 4 & 4 & 4 & 4 & 4 & 4 \\
\hline $\begin{array}{l}\text { Avera } \\
\text { ge } \\
\text { perce } \\
\text { ntage }\end{array}$ & 10 & 75 & 10 & 10 & 10 & 50 & 10 & 10 & 86.2 & 81.4 \\
0 & $0 \%$ & $0 \%$ & $0 \%$ & $\%$ & $0 \%$ & $0 \%$ & $6 \%$ & $2 \%$ \\
\hline
\end{tabular}

Number of participants who submitted the assignment, peer reviewed activities and the marks they have been given is given in Table 9.

Table 9: Number of participants who submitted the assignment, peer reviewed activities and the marks they have been given

\begin{tabular}{|l|c|c|c|}
\hline & $\begin{array}{l}\text { Design } \\
\text { Database } \\
\text { Application } \\
\text { using DDL and } \\
\text { DML }\end{array}$ & $\begin{array}{l}\text { Peer Review of } \\
\text { Database } \\
\text { Application } \\
\text { using DDL and } \\
\text { DML }\end{array}$ & $\begin{array}{l}\text { Total } \\
\text { Marks }\end{array}$ \\
\hline $\begin{array}{l}\text { No of persons } \\
\text { attempted }\end{array}$ & 70 & 70 & 27 \\
\hline Average Marks & 7 & 20 & 30 \\
\hline $\begin{array}{l}\text { Maximum } \\
\text { Marks }\end{array}$ & 10 & 20 & $98 \%$ \\
\hline $\begin{array}{l}\text { Average } \\
\text { Percentage }\end{array}$ & $88 \%$ & $91 \%$ & \\
\hline
\end{tabular}

\section{Analysis of Perception}

We analysed the overall perception of learners through their feedback in the three surveys. In all three survey, the abbreviations are used as follows:
SD- Strongly disagree

MD- Mildly disagree

N- Neutral

MA- Mildly agree

SA- Strongly agree

- Perception of Learning: For each of the parameters to analyse perception of learning as shown in table 10 and figure 7 , it can seen that the students seem to have a good perception about the learning offered by the course [https://docs.google.com/forms/d/e/1FAIpQLSefdVg yXp7kBdBZBusXrZirL ].

Table 10: Perception of Learning

\begin{tabular}{|l|l|l|l|l|l|}
\hline & SD & MD & N & MA & SA \\
\hline $\begin{array}{l}\text { I was able to relate each of the } \\
\text { learning objectives to the } \\
\text { learning I achieved. }\end{array}$ & $2 \%$ & $0 \%$ & $8 \%$ & $25 \%$ & $63 \%$ \\
\hline $\begin{array}{l}\text { I understood the learning } \\
\text { objectives. }\end{array}$ & $0 \%$ & $2 \%$ & $3 \%$ & $27 \%$ & $68 \%$ \\
\hline $\begin{array}{l}\text { I was appropriately challenged } \\
\text { by the course material. }\end{array}$ & $2 \%$ & $0 \%$ & $7 \%$ & $33 \%$ & $58 \%$ \\
\hline $\begin{array}{l}\text { My learning was enhanced due } \\
\text { to the course material. }\end{array}$ & $2 \%$ & $0 \%$ & $0 \%$ & $17 \%$ & $81 \%$ \\
\hline $\begin{array}{l}\text { I will be able to immediately } \\
\text { apply what I learned. }\end{array}$ & $2 \%$ & $0 \%$ & $10 \%$ & $28 \%$ & $60 \%$ \\
\hline $\begin{array}{l}\text { I feel motivated for advanced } \\
\text { training on the subject. }\end{array}$ & $0 \%$ & $0 \%$ & $12 \%$ & $28 \%$ & $60 \%$ \\
\hline $\begin{array}{l}\text { The additional } \\
\text { resources/reference materials } \\
\text { offered in-depth knowledge on } \\
\text { the subject. }\end{array}$ & $1 \%$ & $0 \%$ & $12 \%$ & $20 \%$ & $67 \%$ \\
\hline $\begin{array}{l}\text { I gained a new perspective by } \\
\text { participating in the discussion } \\
\text { forum. }\end{array}$ & $3 \%$ & $0 \%$ & $3 \%$ & $18 \%$ & $76 \%$ \\
\hline
\end{tabular}

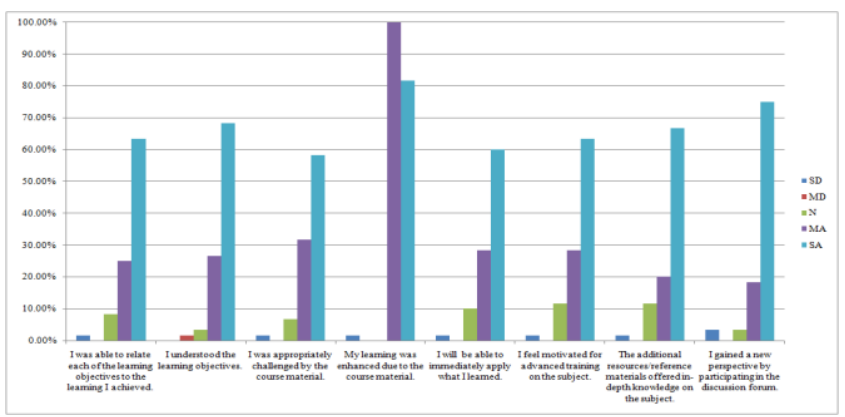

Fig. 7 Analysis of Perception Graph

- Perception of Engagement: It is observed from feedback given in Table 11 and figure 8 that the students are easily able to get actively involved each time they access the course and find the additional resources/reference materials engaging enough [https://docs.google.com/forms/d/e/1FAIpQLSeZ1Uq om0sfF5L17kHjmGxmR ].

Table 11: Perception of Engagement

\begin{tabular}{|l|l|l|l|l|l|}
\hline & SD & MD & N & MA & SA \\
\hline $\begin{array}{l}\text { I was well engaged during the } \\
\text { course. }\end{array}$ & $2 \%$ & $0 \%$ & $5 \%$ & $20 \%$ & $73 \%$ \\
\hline
\end{tabular}




\begin{tabular}{|l|l|l|l|l|l|}
\hline $\begin{array}{l}\text { It was easy for me to get } \\
\text { actively involved each time I } \\
\text { accessed the course. }\end{array}$ & $2 \%$ & $2 \%$ & $7 \%$ & $23 \%$ & $66 \%$ \\
\hline $\begin{array}{l}\text { I was given ample opportunity } \\
\text { to practice the skills I was to } \\
\text { learn. }\end{array}$ & $1 \%$ & $0 \%$ & $7 \%$ & $31 \%$ & $61 \%$ \\
\hline $\begin{array}{l}\text { I found quizzes/activities } \\
\text { interesting. }\end{array}$ & $2 \%$ & $0 \%$ & $3 \%$ & $17 \%$ & $78 \%$ \\
\hline $\begin{array}{l}\text { I found the discussion forum } \\
\text { threads motivating enough to } \\
\text { participate regularly. }\end{array}$ & $3 \%$ & $2 \%$ & $8 \%$ & $20 \%$ & $67 \%$ \\
\hline $\begin{array}{l}\text { I viewed/read all the additional } \\
\text { resources/reference materials. }\end{array}$ & $3 \%$ & $0 \%$ & $11 \%$ & $39 \%$ & $47 \%$ \\
\hline
\end{tabular}

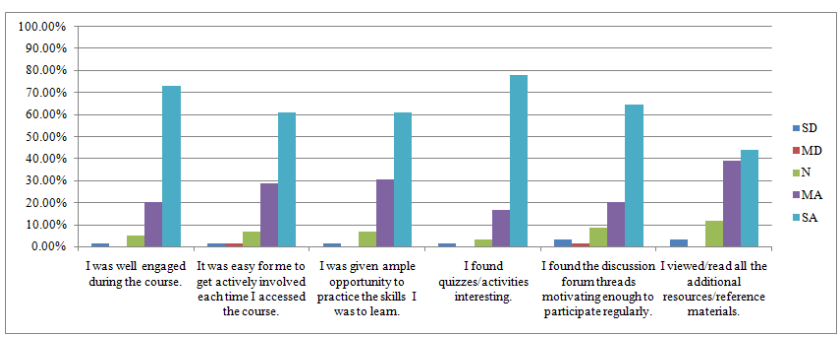

Fig. 8 Perception of Engagement Graph

- Perception of Usability: from feedback shown in Table 12 and figure 9, we can see that most of the participants have agreed in the range of Mildly and Strongly on the usability of the course [https://docs.google.com/forms/d/e/1FAIpQLSd3Rd OOlvCIDgHQo6i2pMRD-].

Table 12: Perception of Usability

\begin{tabular}{|l|l|l|l|l|l|}
\hline & SD & MD & N & MA & SA \\
\hline $\begin{array}{l}\text { I found the course materials } \\
\text { easy to navigate. }\end{array}$ & $2 \%$ & $0 \%$ & $8 \%$ & $18 \%$ & $72 \%$ \\
\hline $\begin{array}{l}\text { I was comfortable with the } \\
\text { pace of the program. }\end{array}$ & $3 \%$ & $1 \%$ & $12 \%$ & $18 \%$ & $66 \%$ \\
\hline $\begin{array}{l}\text { I was comfortable with the } \\
\text { duration of the session. } \\
\text { Show }\end{array}$ & $2 \%$ & $0 \%$ & $8 \%$ & $31 \%$ & $59 \%$ \\
\hline $\begin{array}{l}\text { I found consistency in the } \\
\text { course material design. }\end{array}$ & $1 \%$ & $0 \%$ & $5 \%$ & $27 \%$ & $64 \%$ \\
\hline $\begin{array}{l}\text { I found the course material } \\
\text { clear and and understandable. }\end{array}$ & $1 \%$ & $0 \%$ & $2 \%$ & $19 \%$ & $78 \%$ \\
\hline $\begin{array}{l}\text { I was given ample opportunity } \\
\text { to share } \\
\text { suggestion/feedback. my }\end{array}$ & $2 \%$ & $0 \%$ & $5 \%$ & $25 \%$ & $68 \%$ \\
\hline $\begin{array}{l}\text { I was given ample opportunity } \\
\text { to get answers to my queries. }\end{array}$ & $2 \%$ & $2 \%$ & $1 \%$ & $29 \%$ & $66 \%$ \\
\hline $\begin{array}{l}\text { I found the discussion forum } \\
\text { threads relevant. }\end{array}$ & $1 \%$ & $0 \%$ & $8 \%$ & $19 \%$ & $72 \%$ \\
\hline $\begin{array}{l}\text { I think that I would like to } \\
\text { frequently use what I learnt. }\end{array}$ & $2 \%$ & $0 \%$ & $1 \%$ & $19 \%$ & $78 \%$ \\
\hline
\end{tabular}

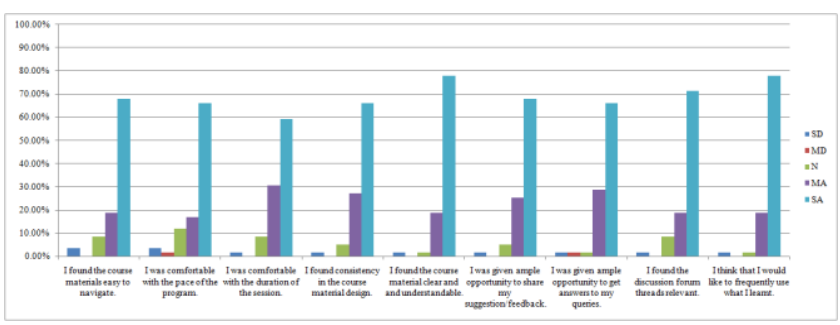

Fig. 9 Perception of Usability Graph

\section{Conclusions}

The gross data about engagement shows that the numbers of students completing the activities/quizzes are good. Also, from the data on scores of students, we can see that the scores of the students in the final Knowledge Quiz (KQ) are also good. The average assignment score is good. This indicates that the perceived learning value of the course is good. This course created using online MOODLE is useful for students from table 6 and 7. Such courses can be created for any course using online MOODLE.

\section{References}

https://en.wikipedia.org/wiki/Moodle accessed on 24th June 2019 https://hurix.com/benefits-moodle-based-learning-management-system/ accessed on 24th June 2019

https://docs.google.com/forms/d/e/1FAIpQLSefdVgyXp7kBdBZBusXrZi rL accessed on 24th June 2019

https://docs.google.com/forms/d///1FAIpQLSeZ1Uqom0sfF5L17kHjmG $\mathrm{xmR}$ accessed on 24th June 2019

https://docs.google.com/forms/d/e/1FAIpQLSd3RdOOlvCIDgHQo6i2p MRD- accessed on 24th June 2019

http://moodle.org/ accessed on $01^{\text {st }}$ July 2019

S. Dol, V. Singh, N. Sahu and M. Shalinie (2018) Designing FDP for "Active Learning-Think-Pair-Share and Peer Instructions" Using Online Learning Management System MOODLE, 2018 IEEE Ninth International Conference on Technology for Education (T4E), Chennai, India, 2018, pp. 190-193.doi:10.1109/T4E.2018.00049.

Sunita M Dol and Trupti S Indi (2017) Open Educational Resource (OER): C-Programming Handout based Lab Session using MOODLE for Engineering Education in Journal of Engineering Education Transformation. DOI: 10.16920/jeet/2017/v0i0/111816

Rana El Bahsh and Mohammad I. Daoud (2016) Evaluating the Use of Moodle to Achieve Effective and Interactive Learning: A Case Study at the German Jordanian University. 978-1-5090-4580-8/16/\$31.00 @2016 IEEE

Naifa E. Saleem et.al. (2016) Acceptance of Moodle as a Teaching/Learning Tool by the Faculty of the Department of Information Studies at Sultan Qaboos University, Oman based on UTAUT. International Journal of Knowledge Content Development \& Technology Vol.6, No.2, 5-27

Andrea North-Samardzic and Monash University (2015) Acceptance and Use of Moodle by Students and Academics. Twenty-first Americas Conference on Information Systems, Puerto Rico, 2015

Lan Umek et.al. (2015) MOODLE E-LEARNING SYSTEM AND STUDENTS'PERFORMANCE IN HIGHER EDUCATION: THE CASE OF PUBLIC ADMINISTRATION PROGRAMMES. International Conference e-Learning

Amandu, G. M., Muliira, J. K., \& Fronda, D. C. (2013). Using Moodle elearning platform to foster student self-directed learning: Experiences with utilization of the software in undergraduate nursing courses in a middle eastern university. Procedia - Social and Behavioral Sciences, 93, 677-683.

Carolina Costa et.al. (2012) The Use of Moodle e-learning Platform: A Study in a Portuguese University. DOI: $10.1016 /$ j.protcy.2012.09.037

Blin F. and M. Munro (2008) Why hasn't technology disrupted academics' teaching practices? Understanding resistance to change through the lens of activity theory. Comput. Educ., 50(2), p. 475-490 